\title{
A CASE OF ACUTE HYPERPYREXIA WITH VIOLENT SHIVERING IMMEDIATELY AFTER OPERATION UNDER EPIDURAL ANAESTHESIA SUPPLEMENTED BY NITROUS OXIDE
}

\author{
M. Yamashita, K. Honda, H. Iha, S. Kondo, A. Matsuki and T. Oyama
}

\begin{abstract}
Acute rise of body temperature to $40^{\circ} \mathrm{C}$ triggered by violent shivering was observed immediately after operation under epidural anaesthesia supplemented by nitrous oxide in a 65 -year-old male patient. Cooling was not effective until the patient was anaesthetized with thiopentone, diazepam, and triflupromazine to control the shivering.
\end{abstract}

KEY WORDS: COMPLICATIONS, postoperative shivering, hyperpyrexia; ANAESTHETICS, gases, nitrous oxide; ANAesthetic TeChniQues, epidural.

SINCE THE recognition of malignant hyperpyrexia as a clinical entity, rise of body temperature during and immediately after anaesthesia has engaged the attention of anaesthetists. ${ }^{1,2} \mathrm{Re}$ cently we have experienced an episode of acute hyperpyrexia triggered by violent shivering immediately after an operation under epidural anaesthesia supplemented by nitrous oxide.

\section{CAse RePort}

A 65 -year-old $45 \mathrm{~kg}$ male, with unremarkable family history, underwent partial resection of the urinary bladder and right ureter for neoplasm. Incidence of hyperpyrexia during or immediately after operation in his family or relatives was not known. Preoperative examinations were unremarkable except for left ventricular hypertrophy on E.C.G. (Table I).

Premedication consisted of intramuscular diazepam $8 \mathrm{mg}$ and atropine sulphate $0.4 \mathrm{mg}$ one hour before anaesthesia. On admission to the operating room, his blood pressure was $124 / 80$ $\mathrm{mmHg}$, heart rate 58 per minute, and body temperature $36.6^{\circ} \mathrm{C}$. An intravenous drip infusion of lactated Ringer's solution was started. The epidural space was identified by the loss of resistance technique and an epidural catheter was introduced at L2,3 and advanced $4 \mathrm{~cm}$ caudad. The aspiration test was negative and the

M. Yamashita, M.D., K. Honda, M.D., H. Iha, M.D., S. Kondo, M.D., A. Matsuki, M.D., T' Oyama, M.D., Department of Anesthesiology, Hirosaki University, School of Medicine, Hirosaki, 036 Japan.

632

Can. Anaesth. Soc. J., vol. 29, no. 6, November 1982 positioning of the catheter was confirmed by administration of a test dose. Thereafter lidocaine 2 per cent was given in $100 \mathrm{mg}$ increments to a total of $300 \mathrm{mg}$, and analgesia was obtained between T11 and L5. The trachea was intubated following intravenous thiopentone $200 \mathrm{mg}$, succinylcholine $40 \mathrm{mg}$ and topical lidocaine. The usual fasciculations were observed following succinylcholine and relaxation of the jaw was satisfactory. The patient was given nitrous oxide $3.5 \mathrm{l} / \mathrm{min}$ and oxygen $1.5 \mathrm{l} / \mathrm{min}$ and the lungs were ventilated manually.

Lidocaine 1.5 per cent was used to a total dose of $1330 \mathrm{mg}$ during the operation, which lasted five hours and three minutes. Ephedrine $4 \mathrm{mg}$ was administered three times when the systolic blood pressure fell below $80 \mathrm{mmHg}$, and intravenous atropine sulphate $0.2 \mathrm{mg}$ when the heart rate slowed to less than 50 beats per minute during anaesthesia. Warming by blanket $\left(39^{\circ} \mathrm{C}\right)$ was started when the rectal temperature dropped to $36.0^{\circ} \mathrm{C}$, but nevertheless it dropped further to $35.1^{\circ} \mathrm{C}$ during two hours in the course of the operation and was $36^{\circ} \mathrm{C}$ at the end of the

TABLE I

Preoperative Examinations

Blood pressure $120 / 60 \mathrm{mmHg}$ Pulse rate 72 beat $/ \mathrm{min}$

Body temperature $36.5^{\circ} \mathrm{C}$

RBC $450 \times 10^{4} / \mathrm{mm}^{3}$ Total protein $61 \mathrm{~g} / 1$

GOT $14 \mathrm{U} / 1$ GPT $21 \mathrm{U} / 1$

BUN $6 \mathrm{mmol} / 1 \quad$ CPK $\quad 73$ l.U. 1

E.C.G. L.V.H. 
TABLE II

Arteriad, Baood Gas Anal,ysis

\begin{tabular}{lcccc}
\hline \hline & Preoperative & $\begin{array}{c}\text { End of } \\
\text { Operation }\end{array}$ & $\begin{array}{c}\text { Shivering } \\
\left(40^{\circ} \mathrm{C}\right)\end{array}$ & $\begin{array}{c}\text { After } 7 \% \mathrm{NaHCO}_{3} \\
60 \mathrm{ml} \mathrm{i.v.}\end{array}$ \\
\hline$\left[\mathrm{H}^{+}\right]_{2} \mathrm{mmol} / 1$ & 41 & 40 & 57 & 44 \\
$\mathrm{PCO}_{2}(\mathrm{kPa})$ & 5.1 & 4.5 & 4.8 & 4.9 \\
$\mathrm{PO}_{2}(\mathrm{kPa})$ & 9.8 & 20.5 & 18.1 & 16.0 \\
$\mathrm{HCO}_{3}(\mathrm{mmol} / \mathrm{l})$ & 23.7 & 20.8 & 14.2 & 19.8 \\
$\mathrm{BE}(\mathrm{mmol} / \mathrm{l})$ & -0.4 & -2.8 & -11.4 & -3.7 \\
\hline
\end{tabular}

operation. Stored whole blood $600 \mathrm{ml}$ was transfused during the operation.

The patient responded to verbal orders and was able to take deep breaths as soon as nitrous oxide had been discontinued; hence the tracheal tube was removed, and he was transferred to the recovery room.

On admission to the recovery room, blood pressure was $120 / 70 \mathrm{mmHg}$, heart rate 76 beats per minute and body temperature $36.0^{\circ} \mathrm{C}$. The patient was alert and orientated without complaints of pain or chill (Figure 1). Fifteen minutes later he developed violent shivering and rise of body temperature followed. Within 50 minutes the rectal temperature had risen to $40^{\circ} \mathrm{C}$, despite the intravenous administration of triflupromazine $15 \mathrm{mg}$, alcohol sponging, cooling blankets and the application of ice bags over the iliac, carotid and popliteal areas. Arterial blood gas analysis revealed metabolic acidosis, and $60 \mathrm{ml}$ of sodium bicarbonate seven per cent was administered (Table II). At this point the decision was made to anaesthetize the patient to terminate the shivering. A total intravenous dose of thiopentone $400 \mathrm{mg}$, diazepam $20 \mathrm{mg}$ and triflupromazine $45 \mathrm{mg}$ succeeded in controlling the shivering and the rectal temperature fell to below $38^{\circ} \mathrm{C}$ within two hours. Cooling was continued until

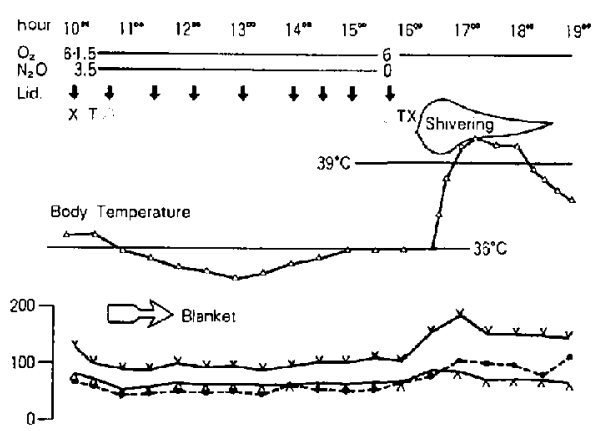

FIGURE 1 Course of anaesthesia. the rectal temperature had dropped to $37.8^{\circ} \mathrm{C}$. The patient was observed closely for another hour while the temperature remained stable, whereupon he was transferred to the intensive observation area of the ward. C.P.K. determined in the recovery room was 267 I.U./l.

A low grade fever (below $38^{\circ} \mathrm{C}$ ) persisted for three days on the ward and then subsided. No further hyperpyrexia followed, and the postoperative course was uneventful.

\section{Discussion}

Acute hyperpyrexia immediately after the operation has been reported recently as being caused by septicaemia, ${ }^{3,4}$ phaechromocytoma, ${ }^{4}$ malfunction of central thermo-regulatory mechanism following neurosurgery ${ }^{5}$ and by malignant hyperpyrexia (including suspected cases). ${ }^{6-11}$ Our case was somewhat unique because the hyperpyrexia was triggered by an episode of violent shivering. This phenomenon has not been described, although hyperpyrexia with shaking chills was included in a couple of reports. ${ }^{3,7,10}$ Kumaya, et al. ${ }^{10}$ reported that a 51-year-old male who underwent an uneventful neurosurgical procedure under halothane anaesthesia developed severe shaking chills after extubation and the body temperature rose from $35.5^{\circ} \mathrm{C}$ to $41.5^{\circ} \mathrm{C}$ in 30 minutes. Ryan and Papper $^{7}$ reported on a female patient who, following an otolaryngological operation under halothane anaesthesia, had a shaking chill after an episode of emergence delirium in the recovery room. The rectal temperature rose from $38.4^{\circ} \mathrm{C}$ to $40.3^{\circ} \mathrm{C}$ in two and a half hours despite the intravenous administration of chlorpromazine $25 \mathrm{mg}$, alcohol baths, cooling blankets and ice bags.

Shivering after epidural anaesthesia is relatively common with an incidence of 20 to 50 per cent. ${ }^{12-14}$ In comparison with patients being given one per cent halothane, patients who had received epidural anaesthesia were slow to re- 
warm in the recovery room despite a high incidence of shivering. ${ }^{14}$

The aetiology of shivering after epidural anaesthesia is unclear. Thauer and Simon ${ }^{15}$ claimed that shivering was a response to the effect of cold solution introduced into the epidural space on temperature sensors located in the spinal cord. However, Webb, James and Wheeler ${ }^{16}$ injected bupivacaine at $15^{\circ} \mathrm{C}, 20^{\circ} \mathrm{C}$, and $37^{\circ} \mathrm{C}$ into the epidural space for obstetrical analgesia, and showed no difference in the incidence of shivering between the groups. Thus they came to the conclusion that the incidence of shivering was independent of the temperature of local anaesthetics injected into the epidural space.

Only a few cases of malignant hyperpyrexia have been reported following regional anaesthesia. ${ }^{11,17-19}$ Klimanak, Majewski and Walehick ${ }^{17}$ reported a case of malignant hyperpyrexia following lumbar epidural anaesthesia with lidocaine $300 \mathrm{mg}$ and bupivacaine $50 \mathrm{mg}$. Muscle rigidity developed in the upper extremities and face with contractions and trismus. The body temperature rose to $41.5^{\circ} \mathrm{C}$ in 30 minutes despite intensive cooling. High temperatures following subarachnoid anaesthesia have been reported by Katz and Virich ${ }^{11}$ by Katz ${ }^{18}$ and Wadhwa. ${ }^{19}$ On the basis of animal experiments, Kerr, Wingard and $\mathrm{Gatt}^{20}$ have claimed that epidural anaesthesia with lidocaine prevents malignant hyperpyrexia.

Our patient was given thiopentone and succinylcholine for tracheal intubation, supplemented with nitrous oxide; thus it was not a pure epidural anaesthesia. Since the hyperpyrexic reaction developed six hours after the administration of succinylcholine which is a prime trigger of malignant hyperpyrexia a diagnosis of malignant hyperpyrexia could probably be excluded. The hyperpyrexia was probably caused by intense shivering from undetermined causes following epidural anaesthesia. In accordance with Pickering"1 that "the most effective means of cooling a man is to give an anaesthetic," successful cooling was achieved only after administration of thiopentone, diazepam, and triflupromazine. In this kind of shivering-triggered hyperpyrexia, shivering must be controlled first, before effective cooling can be achieved.

\section{REFERENCES}

1. Gordon, R.A., Britt, B.A. \& Kalow, W. International symposium on malignant hyperthermia. Springfield: Charles C. Thomas (1973).
2. Britr, B.A. Malignant hyperthermia. Int. Anesth. Clin., Vol. 17, No. 4, Boston, Little Brown (1979).

3. ModeLl, J.H. Septicemia as a cause of immediate postoperative hyperthermia. Anesthesiology 27: 329 (1966).

4. Schweizer, O., Howland, W.S., RYan, G.M, et al. Hyperpyrexia in the operative and immediate postoperative period. Anesth. \& Analg. 50: 906 (1971)

5. TANIOKA, F. NOGUCHI, T. YAMAYA, R., et al Hyperthermia immediately after general anesthesia. Hiroshima J. Anesth. 16: 97 (1980).

6. KENNY, S. \& RolFE, H. Hyperpyrexia after anaesthesia. Brit. Med. J. 4: 492 (1970)

7. Ryan, J.F. \& PAPPer, E.M. Malignant fever during and following anesthesia. Anesthesiology 32: 196 (1970)

8. Beldavs, J., Small, V., Cooper, D.A., et al Postoperative malignant hyperthermia: A case report. Can. Anaesth. Soc. J. 18: 202 (1971).

9. Mukai, M., Nishino, K., Otani, M., et al. A fatal case of hyperpyrexia $\left(42^{\circ} \mathrm{C}\right)$ occurred immediately after operation. Hiroshima J. Anesth. 10: 133 (1974).

10. Kumaya, M., Hiroki, K., Otsuka, M., et al. A case of suspected malignant hyperthermia developed immediately after operation. Hiroshima J. Anesth. 15: (suppl) 10 (1979).

11. KATZ, J.D. \& KRICH, L.B. Acute febrile reaction complicating spinal anaesthesia in a survivor of malignant hyperthermia. Can. Anaesth. Soc. J. 23: 285 (1976)

12. Downing, J.W. Bupivacaine: a clinical assessment in lumbar extradural block. Brit. J. Anaesth. 41: 427 (1969).

13. Waters, H.R., Rosen, N. \& Perkins, D.H Extradural block with bupivacaine. Anaesthesia 25: 184 (1970)

14. Holdcroft, A., Hall, G.M. \& CoOper, G.M Redistribution of body heat during anaesthesia. A compatison of halothane, fentanyl and epidural anaesthesia. Anaesthesia 34: 758 (1979).

15. Thauer, R. \& Simon, E. Spinal cord and temperature regulation. In Ito, S., Ogata, K., and Yoshimura, H. (eds): Advances in Climatio Physiology, Tokyo Igaku Shoin Ltd. 1972, pp. $22-49$.

16. WEBB, P.J., JaMES, III. F.M., \& WHEELER, A.S. Shivering during epidural analgesia in women in labor. Anesthesiology 55: 706 (1981).

17. KlimaneK, J., Majewski, W. \& WaLencik, K. A case of malignant hyperthermia during epidural analgesia. Anaesth. Resus. Inten. Therap. 4: 143 (1976).

18. KATZ, J,D. Malignant hyperthermia during regional anesthesia. Anesthesiology 47: 75 (1977).

19. WADHWA, R.K. Obstetric anesthesia for a patient with malignant hyperthermia susceptibility. Anesthesiology 46: 63 (1977)

20. Kerr, D.D., Wingard, D.W. \& Gatz, E.E. Prevention of porcine malignant hyperthermia by epidural block. Anesthesiology 42: 307 (1975).

21. Pickering, G. Regulation of body temperature in health and disease. Lancet 1:59(1958). (quoted in Hall, G.M. Body temperature and anaesthesia. Brit. J. Anaesth, 50: 39 (1978).) 
RÉSuMÉ

Un épisode subit d'hyperthermie à $40^{\circ} \mathrm{C}$ précédé et accompagné d'un violent frisson est survenu chez un patient de 61 ans immédiatement à la fin d'une intervention d'une durée de 6 heurcs (cystectomie et urétérectomie partielles). L'intervention avait été effectuće sous anesthésie péridurale supplémentée de protoxyde d'azote et d'oxygène. Le malade s'était éveillé en fin d'intervention et avait été extubé avant son transport en salle de réveil. Les mesures de refroidissement (matelas réfrigérant, sacs de glace, éponges d'alcool ct trifluopromazine) se sont avérées inefficaces tant que le frisson a persisté; on a dû recourir à l'anesthésie générale (thiopental, diazepam, triofluopromazine) pour le contrôler. Dans des cas comme celui-ci, où l'hyperthermie est associée au frisson, il faut contrôler le frisson pour en arriver à refroidir le malade. 